\title{
SUBSTITUTION OF DRINKING WATER BY FRUCTOSE SOLUTION INDUCES HYPERINSULINEMIA AND HYPERGLYCEMIA IN HAMSTERS
}

Carlos Magno M. R. Barros, Rosane Q. Lessa, Mauricio P. Grechi, Tanial L. M. Mouço, Maria das Graças C. Souza, Nicolas Wiernsperger, Eliete Bouskela

\begin{abstract}
Barros CMMR, Lessa RQ, Grechi MP, Mouço TLM, Souza MGC, Wiernsperger N. Bouskela E. Substitution of drinking water by fructose solution induces hyperinsulinemia and hyperglycemia in hamsters. Clinics. 2007;62(3):327-34 .
\end{abstract}

PURPOSE: To test the possibility of obtaining a practical and stable model of hyperinsulinemia and hyperglycemia in hamsters, substituting the drinking water by $10 \%$ or $20 \%$ fructose solutions for a period of 2,4 , or 6 months.

METHODS: Male hamsters were divided into 3 main groups, further divided in 3 subgroups: Two months: Group Ia control $(\mathrm{n}=$ 51) received filtered water, Group $\mathrm{Ib}(\mathrm{n}=49)$ received $10 \%$ fructose solution instead of water, Group Ic $(\mathrm{n}=8)$ received $20 \%$ fructose solution instead of water. Four months: Group IIa control $(n=8)$, Group IIb 10\% fructose $(n=7)$, Group IIc $20 \%$ fructose (FIIc, $n=7)$. Six months: Group IIIa control $(n=6)$, Group IIIb 10\% Fructose $(n=6)$, Group IIIc $20 \%$ Fructose $(n=5)$. All groups were fed with the same laboratory diet. The animals were weighed every 2 weeks during the study period. On the final day of each experiment (61st, 121st, and 181st day after the beginning of the study, respectively), the animals were weighed and anesthetized for blood collection to determine plasma glucose and insulin after at least a 12-h fast. Ten animals of group Ia and 10 of group Ib were evaluated to determine changes in macromolecular permeability induced by ischemia/reperfusion as measured in the cheek pouch microcirculation.

RESULTS: Compared to controls, the animals that drank the $10 \%$ or $20 \%$ fructose solution had significantly greater weight gain $(P<.001)$, fasting plasma glucose $(P<.001)$ Reperfusion, after $30 \mathrm{~min}$ ischemia, resulted in an immediate but reversible increase in postcapillary leakage (L) of $89.0 \pm 2.0 \mathrm{~L} / \mathrm{cm}^{2}$ (group Ia - controls), and $116.5 \pm 4.8 \mathrm{~L} / \mathrm{cm}^{2}$ (group Ib $10 \%$ fructose), $P<$ .001.These results suggest that chronic administration of either $10 \%$ or $20 \%$ fructose solutions could be used to experimentally induce a stable hamster model of hyperinsulinemia and hyperglycemia.

CONCLUSION: The model might facilitate the study of basic mechanisms of hyperglycemia and hyperinsulinemia affecting the microvasculature as demonstrated by the findings regarding ischemia/reperfusion after only 2 months of treatment.

KEYWORDS: Insulinemia. Hyperglycemia. Fructose solution. Experimental animal model. Hamster.

\section{INTRODUCTION}

Diabetes mellitus comprises a group of metabolic diseases characterized by hyperglycemia resulting from defects in insulin secretion, insulin action, or both; longterm it is associated with permanent damage, dysfunction, and failure of various organs. ${ }^{1}$ Several pathogenic processes are involved in the development of diabetes,

Laboratory of Research in Microcirculation, University of the State of Rio de Janeiro

Email: eliete_bouskela@yahoo.com.br

Received for publication on August 17, 2006

Accepted for publication on January 03, 2007 ranging from autoimmune destruction of pancreatic bcells (type 1) with consequent insulin defficiency to abnormalities that result in insulin resistance. Type 2 diabetes, which accounts for $90 \%$ to $95 \%$ of those with diabetes, is among the most common of chronic diseases and comprises individuals who have insulin resistance and usually relative (rather than absolute) insulin deficiency. Glucose intolerance and hyperglycemia supervene only when the pancreatic $\beta$-cell is unable to maintain compensatory hyperinsulinemia to overcome tissue resistance to insulin action. ${ }^{2}$

It has been estimated that the number of persons affected with type 2 diabetes worldwide will increase from 135 million to over 300 million by 2025 , with most of 
this increase occurring in developing countries. ${ }^{3}$ This disease is frequently associated with other metabolic abnormalities, sometimes called the "metabolic syndrome" or syndrome $\mathrm{X}$, which includes central obesity, hyperlipidemia, hypertension, and accelerated atherosclerosis; other abnormalities such as sleep apnea may also be associated ${ }^{4-7}$ This cluster of abnormalities is associated with a higher incidence of cardiovascular morbidity and mortality. ${ }^{8}$ The difficulty in avoiding these complications is well known in clinical practice, but an adequate control of glycemia through medical monitoring, adherence to treatment, and awareness of the patient with respect to the disease could delay their appearance. ${ }^{9}$

Experimental models could be very useful in the study of these complications. A good and well used experimental model consists of an intraperitoneal injection of streptozotocin or alloxan, which destroys the pancreas Bcells, the only cells in the body that make a meaningful quantity of insulin ${ }^{10-12}$ and consequently produces models of hyperglycemia and hypoinsulinemia. However, the fastest growing type of diabetes mellitus, type 2 diabetes, characterized by hyperglycemia and hyperinsulinemia, has few well characterized experimental models; as a rule, it is not easily produced in the laboratory. Insulin resistance has been reported in several animal models, including spontaneously hypertensive rats, Zucker fatty rats, insulin receptor substrate-1 (IRS-1)-knockout mice, and fructose-fed rats. ${ }^{13-15}$

The major predisposing factors to type 2 diabetes are obesity, decreased activity, and increasing age. ${ }^{16}$ Epidemiological studies in several countries have shown the influence of the diet composition on insulin action and on plasma glucose levels. Among these studies, it is reported that fructose ingestion causes insulin resistance, hyperglycemia, and hypertriglyceridemia in rats. ${ }^{17,18}$ Fructose-fed Sprague Dawley rats fed with $60 \%$ fructoserich chow (i) for 4 weeks showed a reduction in the uptake of tritiated glucose by adypocytes in vitro and in endothelium-dependent vasodilation induced by acetylcholine in aortic strips, ${ }^{19}$ (ii) for 6 weeks showed a reduction to $80 \%$ in tyrosine phosphorilation of IRS-1 in the soleus muscle, ${ }^{20}$ and (iii) for 40 weeks showed a significant increase in fasting plasma insulin without hyperglycemia, a decrease of muscarinic receptors, an increased dependence on nitric oxide (NO), and an impairment of $\alpha_{2}$-adrenergic-mediated relaxation. ${ }^{21}$ Substitution of drinking water by $10 \%$ fructose solution induced a small increase in glycemia without significant changes in body weight, glycosilated hemoglobin, insulinemia, or triglyceridemia. ${ }^{22}$ Based on these reports, fructose was elected for testing. The objective was to test the possibility of obtaining a practical and stable model of hyperinsulinemia and hyperglycemia in small rodents, such as hamsters, where further studies of the microcirculation (cheek pouch, cremaster, dorsal chamber, etc.) could be performed. The continuous substitution of the drinking water by a fructose solution seemed easier than adding this carbohydrate to the animal chow. Two concentrations of fructose were tested, $10 \%$ and $20 \%$, and the stability of the model was determined by measuring fasting plasma glucose and insulin in these animals at 2,4 , and 6 months after the substitution. The use of this model was tested 2 months after the substitution by measuring changes in macromolecular permeability induced by ischemia/reperfusion in the cheek pouch microcirculation.

\section{MATERIALS AND METHODS}

One hundred and forty-seven male Syrian golden hamsters (Mesocricetus auratus), 7 to 10 weeks old, weighing approximately $100 \mathrm{~g}$, obtained from ANILAB, Paulínia, SP, Brazil, were used. Upon arrival, the animals were maintained in the animal house of the Laboratory for Research in Microcirculation, with temperature controlled at $21.0^{\circ} \pm 1.0^{\circ} \mathrm{C}$ and daylight/dark periods of $12 / 12 \mathrm{~h}$ for 2 weeks. During this period, they received appropriate animal diet for small rodents, Nuvital from Nuvilab, Curitiba, PR, Brazil and filtered water ad libitum. This laboratory diet followed the criteria recommended by AIN- $93^{23}$ and was maintained for all animals during the entire experimental period. After these 2 weeks in the animal house, the hamsters were weighed and divided into 3 main groups: 2 months (Group I), 4 months (Group II), and 6 months (Group III). Each group was further divided into 3 subgroups as follows. Group Ia control $(\mathrm{n}=51)$ continued unchanged, ie, continued to drink filtered water; For Group Ib $(\mathrm{n}=49)$ drinking water was replaced by a $10 \%$ fructose solution; for Group Ic $(\mathrm{n}=8)$ drinking water by a $20 \%$ fructose solution. These 3 groups were followed for 60 days. In the second subdivision of groups, Group IIa control $(n=8)$ continued unchanged, ie, continued to drink filtered water; Group IIb $(\mathrm{n}=7)$ had the substitution of drinking water by a $10 \%$ fructose solution; and Group IIc $(n=7)$ had the substitution of drinking water by a $20 \%$ fructose solution. These 3 groups were followed for 120 days. In the third subdivision, Group IIIa control $(\mathrm{n}=$ 6) continued unchanged, ie, continued to drink filtered water; Group IIIb $(n=6)$ had the substitution of drinking water by a $10 \%$ fructose solution; and Group IIIC $(n=5)$ had the substitution of the drinking water by a 
$20 \%$ fructose solution. These 3 groups were followed for 180 days. All the animals were weighed every 2 weeks to evaluate the gain in body mass in all groups.

The following experiments were performed on the final day of this project: (61st, 121st, and 181st day, respectively), according to protocols approved by the Ethical Committee of the State University of Rio de Janeiro (H36/94), always after a 12-h fast. The animals were anesthetized with an intraperitoneal injection, $0.2 \mathrm{~mL} /$ $100 \mathrm{~g}$ body weight, of sodium pentobarbital (Pentobarbital sodique, Sanofi, France, $60 \mathrm{mg} / \mathrm{mL}$ ), and their body temperature was maintained at $37.5^{\circ} \pm 0.5^{\circ} \mathrm{C}$ with a heating pad controlled by a rectal thermistor (LB750 Thermostat System, Upsala Processdata AB, Sweden). Plasma glucose was evaluated through periorbital puncture using a One Touch $^{\circledR}$ brand basic glucose meter and One Touch test strips (Lifescan Inc, Johnson \& Johnson Co., Milpitas, CA, U.S.A.), always after at least a 12-h fast. Soon after the described process, 20 animals were exsanguinated through cardiac puncture using a syringe and needle. Approximately $2.5 \mathrm{~mL}$ of blood was collected from each animal. Each sample was centrifuged, and the serum was stored in a freezer for subsequent biochemical analysis of insulin assayed by radioimmu- noassay using an ${ }^{125} \mathrm{I}$ insulin kit (BioTrak, AmershamPharmacia Biotech, Piscataway, NJ, USA). ${ }^{21}$ In 20 animals, 10 from Group CIa and 10 from Group FIb, cheek pouches of anesthetized animals were prepared for intravital microscopy. Local ischemia was obtained by clampling the neck of the everted pouch and the increase in microvascular permeability was quantified as leakage of intravenously injected fluorescein isothiocyanate-labelled dextran (FITC-dextran 150; MW = 150000).

In statistical presentations, estimates are given as means \pm standard error of the mean (SEM), unless otherwise noted. Significance tests were done with analysis of variance (ANOVA). Statistical significance was declared when $P<.05$.

\section{RESULTS}

All the subgroups in the 3 groups evolved with progressively increasing body weights throughout the experimental period, but the fructose groups (Ib, Ic, IIb, IIc, IIIb, and IIIc) had significantly higher $(P<.001)$ increases $(\mathrm{Ta}-$ bles 1-3).

Fasting plasma glucose concentrations (mg/dL) were significantly higher in the groups of animals drinking

Table 1 - Variation of body weight $(\mathrm{g})$ in animals treated for 2 months with filtered water, 10\%, or 20\% fructose solution and the standard laboratory diet. Results are expressed as mean \pm SEM.

\begin{tabular}{|c|c|c|c|c|c|c|}
\hline \multirow[t]{2}{*}{ Treatment } & \multicolumn{5}{|c|}{ Time (days) } & \multirow[b]{2}{*}{$\mathrm{P}_{\mathrm{ANOVA}}$} \\
\hline & 0 & 15 & 30 & 45 & 60 & \\
\hline Filtered water $(\mathrm{n}=51)$ & $98,6 \mathrm{~g} \pm 1,05$ & $5,4 \% \pm 0,01$ & $10,5 \% \pm 0,01$ & $16,6 \% \pm 0,01$ & $18,7 \% \pm 0,02$ & $0,0009 *$ \\
\hline Fructose $10 \%$ Solution $(n=49)$ & $99,5 \mathrm{~g} \pm 1,00$ & $10,7 \% \pm 0,01$ & $15,3 \% \pm 0,02$ & $20,3 \% \pm 0,02$ & $28,0 \% \pm 0,02$ & \\
\hline Fructose $20 \%$ Solution $(\mathrm{n}=8)$ & $97,6 \mathrm{~g} \pm 1,47$ & $9,8 \% \pm 0,03$ & $15,6 \% \pm 0,02$ & $22,7 \% \pm 0,03$ & $31,0 \% \pm 0,03$ & \\
\hline
\end{tabular}

Table 2 - Variation of body weight (g) in animals treated for 4 months with filtered water, $10 \%$, or $20 \%$ fructose solution and the standard laboratory diet. Results are expressed as mean \pm SEM.

\begin{tabular}{|c|c|c|c|c|c|c|}
\hline \multirow[t]{2}{*}{ Treatment } & \multicolumn{6}{|c|}{ Time (months) } \\
\hline & 0 & 1 & 2 & 3 & 4 & $\mathrm{P}_{\text {ANOVA }}$ \\
\hline Filtered water $(n=8)$ & $94,0 \mathrm{~g} \pm 1,31$ & $8,3 \% \pm 0,02$ & $19,2 \% \pm 0,03$ & $22,8 \% \pm 0,02$ & $24,3 \% \pm 0,02$ & $0,0006 *$ \\
\hline Fructose $10 \%$ Solution $(n=7)$ & $97,2 \mathrm{~g} \pm 1,12$ & $14,6 \% \pm 0,01$ & $30,3 \% \pm 0,02$ & $34,1 \% \pm 0,02$ & $41,5 \% \pm 0,01$ & \\
\hline Fructose $20 \%$ Solution $(n=7)$ & $98,9 \mathrm{~g} \pm 1,19$ & $16,2 \% \pm 0,02$ & $29,7 \% \pm 0,02$ & $37,4 \% \pm 0,02$ & $43,6 \% \pm 0,03$ & \\
\hline
\end{tabular}

Table 3 - Variation of body weight $(\mathrm{g})$ in animals treated for 6 months with filtered water, 10\%, or 20\% fructose solution and the standard laboratory diet. Results are expressed as mean \pm SEM.

\begin{tabular}{|c|c|c|c|c|c|c|c|c|}
\hline \multirow[t]{2}{*}{ Treatment } & \multicolumn{7}{|c|}{ Time (months) } & \multirow[b]{2}{*}{$\mathrm{P}_{\text {ANOVA }}$} \\
\hline & 0 & 1 & 2 & 3 & 4 & 5 & 6 & \\
\hline Filt. water $(n=6)$ & $101,4 \mathrm{~g} \pm 1,24$ & $6,8 \% \pm 1,19$ & $16,8 \% \pm 1,19$ & $19,7 \% \pm 1,19$ & $23,0 \% \pm 1,19$ & $25,1 \% \pm 1,19$ & $28,5 \% \pm 1,19$ & $0,0001 *$ \\
\hline F10\% Sol. $(n=6)$ & $97,5 \mathrm{~g} \pm 1,16$ & $13,2 \% \pm 1,19$ & $28,4 \% \pm 1,19$ & $33,5 \% \pm 1,19$ & $39,2 \% \pm 1,19$ & $42,9 \% \pm 1,19$ & $44,7 \% \pm 1,19$ & \\
\hline F20\% Sol. $(n=5)$ & $97,6 \mathrm{~g} \pm 1,18$ & $14,8 \% \pm 1,19$ & $31,5 \% \pm 1,19$ & $38,1 \% \pm 1,19$ & $43,8 \% \pm 1,19$ & $46,9 \% \pm 1,19$ & $47,6 \% \pm 1,19$ & \\
\hline
\end{tabular}



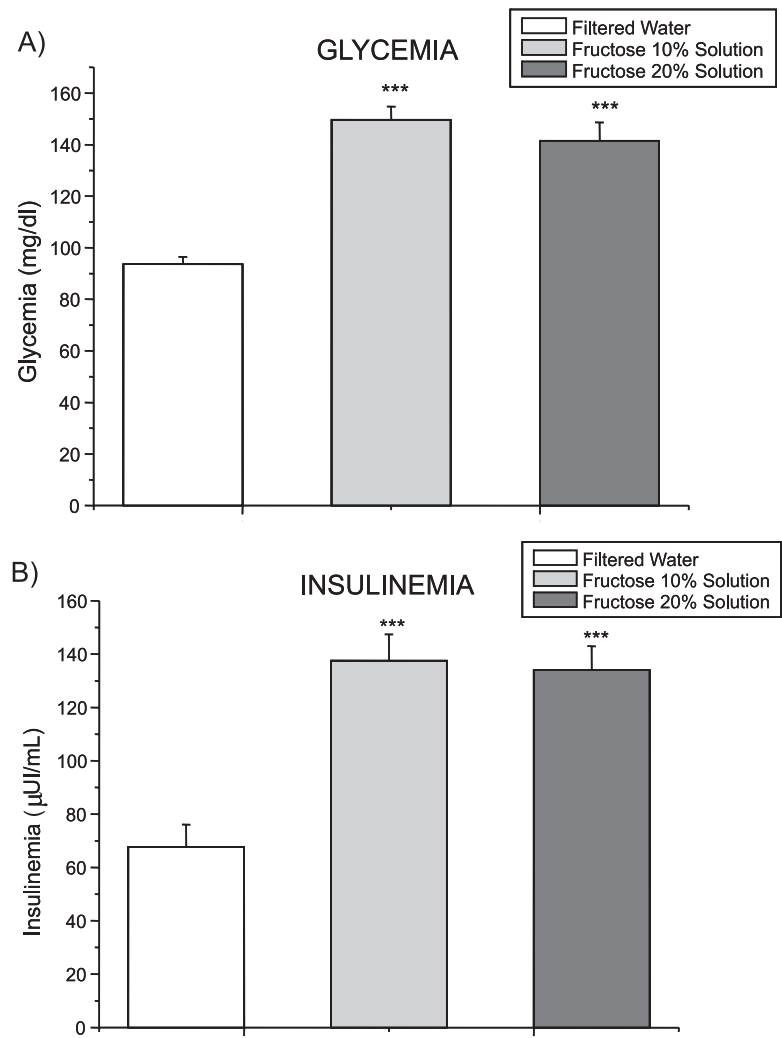

Figure 1 - Effects on glycemia (a) and insulinemia (b) of filtered water, 10\% fructose solution, or $20 \%$ fructose solution on animals treated for 2 months. Results expressed as mean $\pm \mathrm{SEM} ; * * *=P<.001$ compared to controls.

A)

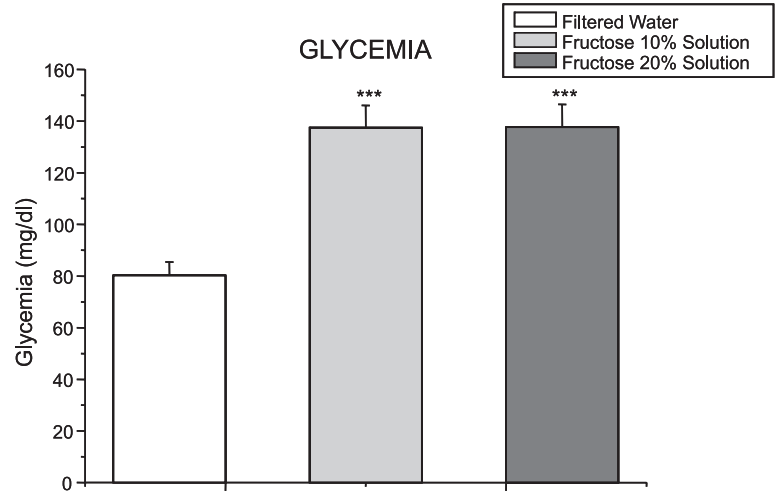

B)

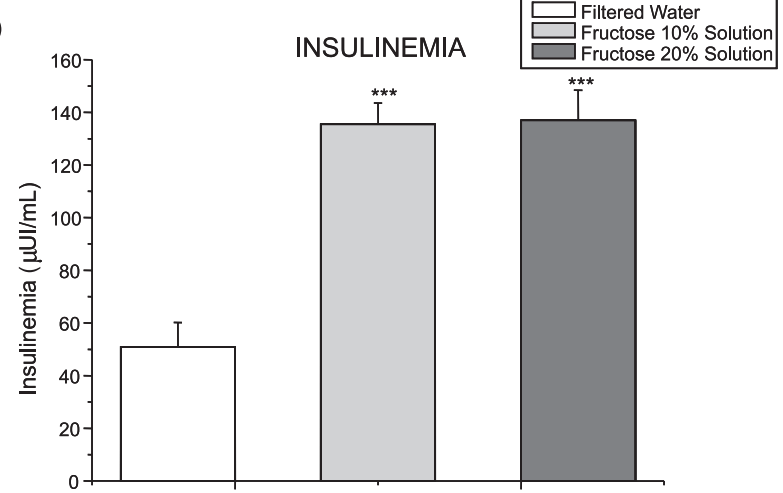

Figure 2 - Effects on glycemia (a) and insulinemia (b) of filtered water, 10\% fructose solution, or $20 \%$ fructose solution on animals treated for 4 months. Results expressed as mean $\pm \mathrm{SEM} ; * * * * P<.001$ compared to controls.
$10 \%$ or $20 \%$ fructose solutions compared to the ones drinking filtered water during the 3 experimental periods, as follows: Ia, $93.6 \pm 2.9$; Fib, $149.6 \pm 5.2$; Fic, $141.5 \pm 7.1, P<.001$ (Figure 1a); CIIa, $80.3 \pm 5.2 ; \mathrm{FIIb}$, $137.5 \pm 8.6$; FIIc, $137.7 \pm 8.8, P<.001$ (Figure 2a); and CIIIa, $88.4 \pm 2.3$; FIIIb, $136.0 \pm 5.6$; FIIIc, $137.7 \pm 8.8$, $P<.001$ (Figure 3a). No difference was observed between 10 vs. $20 \%$ fructose treatment, in any of the three main groups.

Similarly, fasting plasma insulin concentrations $(\mu \mathrm{UI} /$ $\mathrm{mL}$ ) were significantly higher in the groups of animals drinking $10 \%$ or $20 \%$ fructose solutions compared to the ones drinking filtered water during the 3 experimental periods, as follows: CIa, $67.7 \pm 8.4$; FIb $137.5 \pm 9.9$; FI, $134.1 \pm 8.9, P<.001$ (Figure 1b); CIIa, $50.9 \pm 9.3$; FIIb, $135.5 \pm 8.0$; FIIc, $137.0 \pm 11.4, P<.001$ (Figure 2b); and CIIIa, $78.7 \pm 4.5$; FIIIb, $125.0 \pm 12.7$; FIIIc, $126.6 \pm 11.2, P<.001$ (Figure 3b). Again, no difference was observed between 10 vs. $20 \%$ fructose treatment, in any of the three main groups.

Reperfusion, after 30 min ischemia, resulted in a significant immediate, but reversible, increase in postcapillary leakage (L) in Group FI compared with Group CI of $116.5 \pm$ $4.8 \mathrm{~L} / \mathrm{cm}^{2}$ vs $89.0 \pm 2.0 \mathrm{~L} / \mathrm{cm}^{2}$, respectively $(P<.001)$.

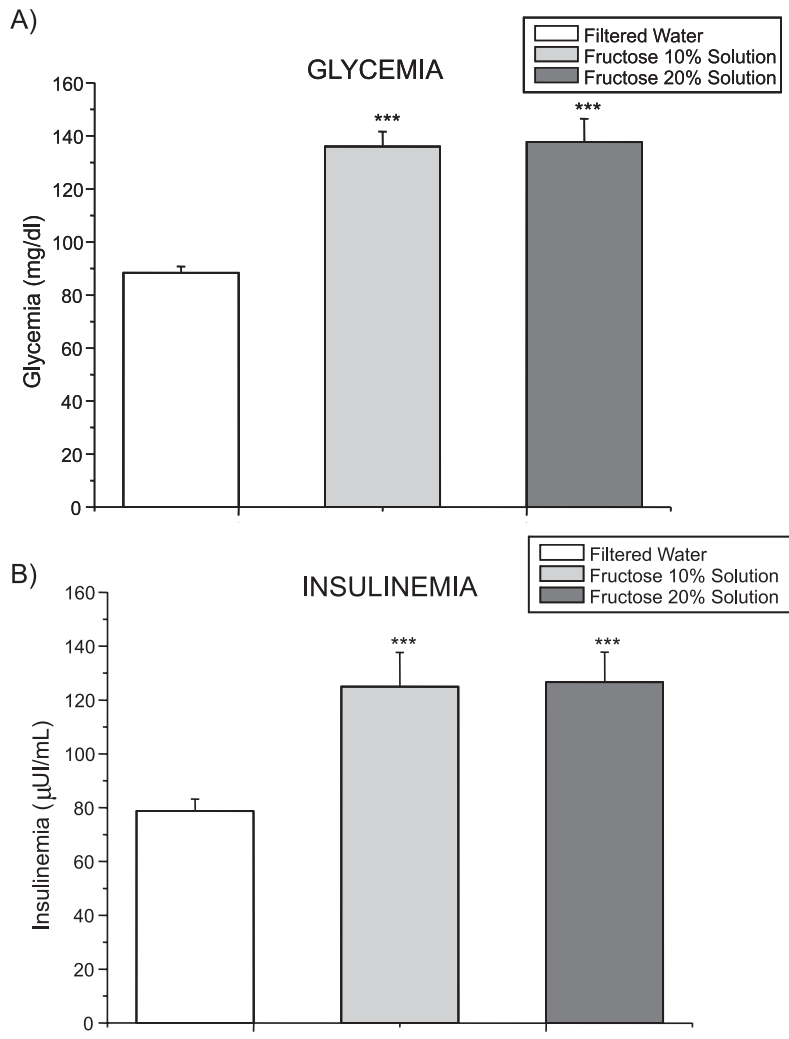

Figure 3 - Effects on glycemia (a) and insulinemia (b) of filtered water, 10\% fructose solution, or $20 \%$ fructose solution on animals treated for 6 months. Results expressed as mean $\pm \mathrm{SEM} ; * * *=P<.001$ compared to controls. 
Differential duration of the experimental period did not cause significant changes in the studied parameters, which strongly suggests that the model is stable.

\section{DISCUSSION}

The effect of chronic treatment with fructose on body weight has been well established experimentally. ${ }^{24}$ Previous studies in our laboratory have demonstrated that the substitution of drinking water by $10 \%$ fructose solution increases weight gain when used continuously for 2, 4, and 6 months. ${ }^{25,26}$ Since fructose consumption in the diet in the form of sacarose is increasing in industrialized and developing countries, this is important information for the public health system.

The increase in body mass was greater in the groups that drank $10 \%$ or $20 \%$ fructose solution (Ib, Ic, IIb, IIc, IIIb, and IIIc) compared to those that drank filtered water (Ia, IIa, and IIIa). This result may be explained by an increase in total caloric intake by the fructose groups during the experimental period. Fructose is an energygenerating molecule that helps to build and maintain body mass. The observed increase in plasma insulin levels in these groups could also contribute to the weight gain. Insulin, a hormone essential for life, exerts critical control over carbohydrate, fat, and protein metabolism. Control animals (filtered water) did not show the same weight gain because water is not an energy-generating molecule, and no increase in plasma insulin levels was detected in these groups (Ia, IIa, and IIIa). However, using a similar model, namely substitution of drinking water by $10 \%$ fructose solution for 18 weeks, Félétou and co-workers ${ }^{22}$ found no significant increase in body weight compared to control hamsters.

Glucose homeostasis in the fasting state is the balance between glucose production by the liver and glucose utilization by muscle and fat. Although the finetuning of glucose metabolism may be influenced by many hormones and metabolic intermediates, normal glucose disposal depends primarily on 4 factors: (1) the ability of the body to secrete insulin acutely and in a sustained fashion, (2) the ability of insulin to inhibit hepatic glucose output, (3) the ability of glucose to promote glucose disposal or insulin sensitivity, and (4) the ability of glucose to enter the cells in the absence of insulin. ${ }^{27}$ The pathogenesis of type 2 diabetes appears to involve at least 2 defects in this regulation system. The earliest detectable lesion is insulin resistance in peripheral tissues ${ }^{16,28,29}$ progressing to hyperinsulinemia and hyperglycemia.

In our studies, animals subjected to substitution of drinking water by $10 \%$ fructose solution showed a significant increase in glycemia, similar to findings reported by Hwang and co-workers ${ }^{30,31}$ and Félétou and co-workers. ${ }^{32}$ Addition of fructose to the diet of rats for a long period also elicited an increase in plasma insulin levels. ${ }^{33}$ In the present study, however, the extent of the metabolic changes induced by fructose was markedly more severe than that reported under similar experimental conditions ${ }^{22}$ where only glycemia was significantly different from controls. In various animal models, including hamsters, hyperinsulinemia, hypertriglyceridemia, hypercholesterolemia, and insulin resistance have been reported with a fructose-enriched diet. ${ }^{34,35} \mathrm{In}$ contrast, fasting glycemic levels were not affected in those studies. These discrepancies with the present study could be explained primarily by the severity of the diet. Most studies are performed with food containing fructose that was $60 \%$ of the total caloric intake, ${ }^{30}$ leading to a daily intake of approximately $16 \mathrm{~g}$ of fructose/hamster ${ }^{33}$ instead of the 1 to $2.4 \mathrm{~g}$ ingested in the present study. There is no significant difference in the substitution of drinking water by either a $10 \%$ or $20 \%$ fructose solution, probably because, even with the $20 \%$ fructose solution, the ingestion of fructose is low. ${ }^{30,34}$ The present study measured nonfasting plasma glucose and insulin while other works reported fasting plasma glucose and insulin.

Most of the metabolic effects of fructose are possibly due to its rapid utilization by the liver and its bypassing the phosphofructokinase regulatory step, with clear consequencences to carbohydrate and lipid metabolism, such as hepatic increase in pyruvate and lactate production, activation of pyruvate dehydrogenase, and a balance change from oxidation to esterification of nonesterified fatty acids, resulting in increased secretion of very-low-density-lipoprotein (VLDL). ${ }^{35}$ The long-term consequence of fructose absorption leads to triglyceridemia, decreased glucose tolerance, and hyperinsulinemia. ${ }^{36}$

The finding that the hyperglycemia is accompanied by hyperinsulinemia after a continuous use of $10 \%$ or $20 \%$ fructose solution for at least 2 months, similarly to what is found in type II diabetic patients, suggests that this could be a model for experimentally studying vascular damages elicited by these changes as well as the efficacy of possible treatments. The results obtained regarding the increase in macromolecular permeability induced by ischemia/reperfusion show that this model is useful for demonstrating the effects of increased plasma glucose and insulin on the microcirculation even after only 2 months of substitution of drinking water by a $10 \%$ 
fructose solution. One advantage of this model is its temporal stability. Moreover, the substitution of the drinking water by a $10 \%$ fructose solution is easier to accomplish than the addition of fructose to the laboratory diet offered to the animal.

\section{ACKNOWLEDGEMENTS}

The study was supported by grants from the National Research Council [CNPq, 521850/96-7 (NV)] and from the Research Supporting Agency of Rio de Janeiro State (FAPERJ E-26/150.141/99 and E-26/170.522/00).
Barros CMMR, Lessa RQ, Grechi MP, Mouço TLM, Souza MGC, Wiernsperger N. Bouskela E. Substituição da água por solução de frutose induz hiperinsulinemia e hiperglicemia em hamster. Clinics. 2007;62(3):327-34.

OBJETIVO: Testar a possibilidade de obtenção de um modelo prático e estável de hiperinsulinemia e hiperglicemia em hamsters substituindo a água de beber por soluções de frutose a $10 \%$ ou $20 \%$ por um período de dois, quatro ou seis meses.

MÉTODOS: Hamsters machos foram divididos em 3 grupos e cada grupo subdividido em 3 subgrupos. Dois meses: Grupo Ia-controle $(n=51)$, recebeu água filtrada, Grupo Ib-(n=49), recebeu solução de frutose a $10 \%$ ao invés de água e Grupo Ic- $(n=8)$, recebeu solução de frutose a $20 \%$ ao invés de água. Quatro meses: Grupo IIa - controle $(n=8)$, Grupo IIb - 10\% frutose $(n=7)$ e Grupo IIc - $20 \%$ frutose $(n=7)$. Seis meses: Grupo IIIa - controle $(n=6)$, Grupo IIIb - 10\% frutose (n=6) e Grupo IIIc - 20\% frutose $(n=5)$. Todos os animais foram alimentados com a mesma dieta padrão de laboratório. Os animais foram pesados a cada 2 semanas durante o período do estudo. No dia do final do experimento $\left(61^{\circ}, 121^{\circ}\right.$ e $181^{\circ}$ dia, respectivamente, após o início do estudo), os animais foram pesados e 
anestesiados para coleta de sangue para determinação da glicose e da insulina sérica, após jejum de pelo menos $12 \mathrm{~h}$. Em 10 animais do grupo Ia e em 10 do grupo Ib avaliamos, na microcirculação da bolsa da bochecha, a variação da permeabilidade a macromoléculas induzida por isquemia/ reperfusão.

RESULTADOS: Comparados ao grupo controle, os animais que beberam soluções de frutose a 10 ou $20 \%$ tiveram um aumento significativo de massa corporal $(\mathrm{p}<0,001)$ e da glicemia de jejum $(\mathrm{p}<0,001)$. Durante o experimento de reperfusão, após 30 min de isquemia, houve um aumento imediato e reversível do extravasamento (E) pós-capilar de $89,0 \pm 2,0 \mathrm{E} / \mathrm{cm}^{2}$ (grupo Ia) e 116,5 $\pm 4,8$ $\mathrm{E} / \mathrm{cm}^{2}$ (grupo Ib), $\mathrm{p}<0,001$.

CONCLUSÃO: Esse estudo sugere que a utilização crônica de solução de frutose a $10 \%$ ou $20 \%$ pode ser usada para induzir experimentalmente um modelo estável de hiperinsulinemia e hiperglicemia em hamsters. Este modelo deverá facilitar o estudo de mecanismos básicos que alteram a microcirculação, como demonstrado pelos achados em isquemia/reperfusão já aos 2 meses.

UNITERMOS: Insulinemia, Glicemia, Solução de frutose, Modelo experimental, Hamster.

\section{REFERENCES}

1. American Diabetes Association. Diagnosis and classification of diabetes mellitus. Diabetes Care. 2006;29 (suppl.1):S43-S48.

2. Goldberg RB. Prevention of type 2 diabetes. Med Clin North Am. 1998;82:805-21.

3. Salles GF, Bloch KV, Cardoso CR. Mortality and predictors of mortality in a cohort of Brazilian type 2 diabetic patients. Diabetes Care. 2004;27:1299-1305.

4. Hales CN, Barker DJ, Clark PM, Cox LJ, Fall C, Osmond C, et al. Fetal and infant growth and impaired glucose tolerance at age 64. BMJ. 1991;303:1019-22.

5. Reaven GM. Pathophysiology of insulin resistance in human disease. Physiol Rev. 1995;75:473-86.

6. Mayfield J. Diagnosis and classification of diabetes mellitus: new criteria. Am Ac. Family Physicians. 1998;58:1355-62:1369-70.

7. Wiernsperger N, Nivoit P, Bouskela E. Obstructive sleep apnea and insulin resistance: a role for microcirculation? Clinics, 2006;61:253-266.
8. Fagan TC, Deedwania PC. The cardiovascular dysmetabolic syndrome. Am J Med. 1998;105(IA):77S-82S.

9. Maki KC. Dietary factors in the prevention of diabetes mellitus and coronary artery disease associated with the metabolic syndrome. Am J Cardiol. 2004;93(11A):12C-17C.

10. Lash JM, Bohlen HG. Structural and functional origins of supressed acetylcholine vasodilation in diabetic rats intestinal arterioles. Circ Res. 1991;69:1259-68.

11. Maree A, Peer G, Iaina A, Blum M, Wollman Y, Csernihovsky T, et al. Nitric oxide in streptozotocin-induced diabetes mellitus in rats. Clinical Science. 1996;90:379-84.

12. Shostak A, Gotloib L. Increased peritoneal permeability to albumin in streptozotocin diabetic rats. Kidney Int. 1996;49:705-14.

13. Pitre M, Nadeau A, Bachelard H. Insulin sensitivity and hemodynamic responses to insulin in Wistar-Kyoto and spontaneously hypertensive rats. Am J Physiol. 1996;271:E658-E668. 
14. Anai M, Funaki M, Ogihara T, Terasaki J, Inukai K, Katagiri H, et al. Altered expression levels and impaired steps in the pathway of phosphatidyl-inositol 3-kinase activation via insulin receptor substrates 1 and 2 in Zucker fatty rats. Diabetes. 1998;47:13-23.

15. Yamauchi T, Tobe K, Tamemoto H. Insulin signaling and insulin actions in the muscle and livers of insulin-resistant, insulin receptor substrate 1-deficient mice. Mol Cell Biol. 1996;16:3074-3084.

16. Kahn CR. Insulin action, diabetogenIs and the cause of type II diabetes (Banting Lecture). Diabetes. 1994;43:1066-84.

17. Zavaroni I, Sanders S, Scott S, Reaven GM. Effect of fructose feeding on insulin secretion and insulin action in the rat. Metabolism. 1980;29:970-3.

18. Tobey TA, Mondon CE, Zavaroni I, Reaven GM. Mechanism of insulin resistance in fructose-fed rats. Metabolism. 1982;31:608-12.

19. Kotchen TA, Reddy S, Zhang HY. Increasing insulin sensitivity lowers blood pressure in the fructose-fed rat. Am J Hypertens. 1997;10:10206.

20. Hyakukoku M, Higashiura K, Ura N, Murakami H, Yamaguchi K, Wang $\mathrm{L}$, et al. Tissue-specific impairment of insulin signaling in vasculature and skeletal muscle of fructose-fed rats. Hypertens Res. 2003;26:16976.

21. Takagawa Y, Berger ME, Hori MT, Tuck ML, Golub MS. Long-term fructose feeding impairs vascular relaxation in rat mesenteric arteries. Am J Hypertens. 2001;14:811-17.

22. Félétou M, Boulanger M, Staczek J, Broux O, Duhault J. Fructose diet and VEGF-induced plasma extravasation in hamster cheek pouch. Acta Pharmacol Sin. 2003; 24:207-11.

23. Reeves PG, Nielsen FH, Fahey Jr. GC. AIN-93 purified diets for laboratory rodents: final reports of the American Institute of Nutrition ad Hoc writing committee on the reformulation of the AIN-76A Rodent Diets. Am Inst Nut. 1993;1939-50.

24. Park OJ, Cesar D, Faix D, Wu K, Shackleton CH, Hellerstein MK. Mechanisms of fructose-induced hypertriglyceridemia in the rat. Activation of hepatic pyruvate dehydrogenase through inhibition of pyruvate dehydrogenase kinase. Biochem J.1992;282(15)(Pt 3):753-7.
25. Grechi MP, Lessa RQ, Barros CMMR, Souza, MGC, Bouskela E. Efeito do tratamento por quatro meses com soluções de frutose a 10 e $20 \%$ sobre a permeabilidade microvascular em hamsters após isquemiareperfusão. Resumos do Congresso SOHERJ 1999;27.

26. Grechi MP, Lessa RQ, Barros CMMR, Souza, MGC, Bouskela E. Effects of fructose $20 \%$ solutions on macromolecular permeability in the microcirculation. FASEB J. 2000;14:A12.

27. Bergman RN, Steil GM, Bradley DC, Watanabe RM. Modeling of insulin action in vivo. Annu Rev Physiol. 1992;54:861-83.

28. Bogardus C, Lillioja S, Bennett PH. Pathogenesis of NIDDM in Pima Indians. Diabetes Care. 1991;14:685-90.

29. Martin BC, Warram JH, Krolewski AS, Bergman RN, Soeldner JS, Kahn CR. Role of glucose and insulin resistance in development of Type II diabetes mellitus: results of a 25-year follow-up study. Lancet. 1992;340:925-9.

30. Hwang IS, Ho H, Hoffman BB, Reaven GM. Fructose-induced insulin resistance and hypertension in rats. Hypertension. 1987;10:512-6.

31. Huang BW, Chiang MT, Yao HT, Chiang W. The effect of high-fat and high-fructose diets on glucose tolerance and plasma lipid and leptin levels in rats. Diabetes Obes Metab. 2004;6:120-6.

32. Félétou M, Bonnardel E, Canet E. Bradykinin and changes in microvascular permeability in the hamster cheek pouch: role of $\mathrm{NO} . \mathrm{Br}$ J Pharmacol. 1996;118:1371-6.

33. Iyer SN, Katovich MJ. Fructose feeding in rats is not associated with sodium retention. Am J Hypertens. 1996;9:1018-23.

34. Kasim-Karakas SE, Vriend H, Almario R, Chow LC, Goodman MN Effects of dietary carbohydrates on glucose and lipid metabolism in golden Syrian hamsters. J Lab Clin Med. 1996;128:208-13.

35. Taghibiglou C, Carpentier C, Van Iderstine SC, Chen B, Rudy D, Ailton Al. Mechanisms of hepatic very low-density lipoprotein overproduction in insulin resistance. J Biol Chem. 2000;275:8416-25.

36. Mayes PA. Intermediary metabolism of fructose. Am J Clin Nutr 1993;58(suppl):754S- 765S 